\title{
Identification of Justification Types and Discourse Markers in Turkish Language Teacher Candidates' Argumentative Texts
}

\author{
Esra Nur Tiryaki ${ }^{1}$ \\ ${ }^{1}$ Mustafa Kemal University, Faculty of Education, Department of Turkish Education, Hatay, Turkey \\ Correspondence: Esra Nur Tiryaki, Asst. Prof. Dr., Mustafa Kemal University, Faculty of Education, Department of \\ Turkish Education, Hatay, Turkey.
}

Received: November 30, 2016

Accepted: December 27, 2016 Online Published: December 28, 2016

doi:10.11114/jets.v5i2.2033

URL: http://dx.doi.org/10.11114/jets.v5i2.2033

\begin{abstract}
The purpose of this research is to identify discourse markers used in justification types in Turkish language teacher candidates' argumentative texts. Survey model was used since it was aimed to determine the categories into which support and refutation justifications are split and to identify the discourse markers which express these categories. It is a descriptive field research in which qualitative data analysis techniques were employed. The pool of the research was obtained from the texts of $3^{\text {rd }}$ and $4^{\text {th }}$ year students $(\mathrm{N}=100)$ in Turkish Language Teaching Department at Mustafa Kemal University, in 2014-2015 academic year (N=100). "Argumentative Text Writing Form" and "Justification Type Identification Form" developed by researcher used as data collection tools. Texts were by using content analysis method. Descriptive statistics (frequency (f), percentage (\%)) analyses were used in the analysis of the data collected in this study. According to the results of this study; a total of 275 justifications including support justifications $(f=225)$ and refutation justifications $(f=50)$ were presented in the texts given by the students. Justification types, which are most widely used for support justifications, are reasoning (\% 19.11), addition (\%14.22), exemplification (\%13.77) and opposition (\%11.55). The least used justification types are distinction (\%2.66), condition (\%2.22) and sequencing (\%1.77). Opposition (\%34) is the most widely used justification type for refutation justifications whereas conclusion, distinction and sequencing (\%2) are the least used ones. Discourse markers $(n=62)$ were identified in 11 justification types. Examples, where these discourse markers were employed, are presented in the study through sample sentences.
\end{abstract}

Keywords: Argumentative texts, justification, Turkish language teaching, writing teaching, discourse marker

\section{Introduction}

Writing, which is among the four basic language skills, depends on individuals' ability in proper use of written language to express their thoughts and feelings. In this conjecture, writing is a difficult art which contains different levels. It takes quite some time for a person to create a consistent and meaningful text in a right form. Text is a consistent and meaningful structure formed by words, sentences, and paragraphs coming together on a verbal and written plane. Discourse examines the relationship between statements. "With Z. Harris' studies which examine sentences as well in distributional aspects, there appears a new field (discourse analysis) of linguistics. Thus, rules regarding articulation of sentences have been studied and distributional criteria and transformational criteria also gave direction to studies" (Vardar, 2002). According to Günay (2013), although text is a structure presented within the scope of communication, discourse is formed as soon as it is used. Text gains concreteness with discourse. During interpretation, text is formed by the help of discourse. Texts are persistent since the expressions in verbal language are converted into systematic units within a particular order and context. This persistence is sourced from the strong links in the semantic dimensions and from the systematic structures in the formal dimensions. Therefore, text is an aimed union of expressions (Tiryaki and Yilmaz, 2016) and is examined in three different categories, namely, informative, narrative and argumentative.

Argumentative text discussed within the scope of this research consists of the persuasion process of the reader by author's justified claims about a topic. In argumentative texts, there are differences in the opinions of the supporter and the target audience. The person, who constantly renews this difference, strengthens his/her claim by providing evidence. Amossy Ruth (2003) noted that proof analysis has 6 basic principles: linguistic, communicative, dialogic, interactive, generic, stylistic and textual approach. In this definition, these principles have been classified based on the properties of language used by the prover. The approach taken in this study is textual. Textual approach, and the text which is the 
subject of discourse analysis, are the consistent integrity of statements which form the written or verbal claim. In this regard, proof refers to the meaning of the consistently integrated statements (Günay, 2013).

Adam (1992) classified argumentative text in a simple way as "entry, claims, counter-claims and results". This text structure is composed of main and auxiliary elements (Quote by Akıguet and Piolat, 1996). Main elements are data, claims, counter-claims and results. Justifications constitute the secondary elements. Justifications are discussed in two parts as support justifications and refutation justifications. Support justifications are the explanations and evidences used by author to strengthen their claims (Nussbaum and Schraw, 2007). This type of justification can be used not only for the claims but also for the counter-claims in order to increase persuasiveness. Evidences used by author to refute counter-claim are called refutation justifications. In both types of justifications, the author forms the language and expression forms to convince the reader of the veracity of his/her views accordingly. He/She uses positive statements to defend his/her claims whereas he/she uses negative statements to refute counter-claims. This is because of the fact that (in the proof texts where this is the sole purpose of the author who tries to convince the audience, anxiety of producing a meaning is evident Günay, 2007).

Toulmin (1958) defined justifications in argumentation model as the elements which strengthen the link between data and claims. In argumentative texts, the author begins to provide justifications after describing his/her claim. The level of language used during the presentation of justifications points out the connections and consistency among the justifications. Deduction and analogy are used in these text formats. According to Günay (2007), in deduction method, with reference to the opinion adopted, the opinion to be imposed is achieved. This proof consists of logical inclusiveness, mutual assumption rule and reason-result relationship. Analogical evidences are based on similarity. "With R. Jakobsun's words; "proofing is a kind of evocation function of the language". The discourse containing proof tries to change thoughts, beliefs and opinions of the receiver. According to O. Ducrot, reasoning and proof are related with entirely different planes; reasoning is related with logic whereas proof is related with discourse. For example, in native languages, some words have a proving function more than semantic content transmission function: "But, yet, because, then." Other than this, the intention of the speaker is the main factor "(Kiran, 2006).

"Justification" is defined in the dictionary as persuasion of or convincing the opponent by making use of argument, reason and result, diversion and justification. Justification explains its discourse with the statements used by the speaker and by their meanings. This is named as "justification in the language" (fr. argumentation dans la langue). According to this approach, the discourse of justification can be associated with grammar rules in both respects; enunciation use (fr. énonciation) and justification. A certain number cannot be used to express justification types so in the classification that have been made, five basic facts have been used to express the types (Öztin Passerat, 2013):

\section{Description}

$>$ Purposive (description depending on types or description by categorising)

$>$ Semantic expansion (description based on the meaning of the word)

2. Causality

$>$ Reason types

$>$ Based on the results

3. Similarities and comparisons

4. Opposition

5. Based on situation and the context

Justifications are the structures that have the argumentation functions. It connects a sentence to another sentence. According to Ducrot (1983), it is divided into two groups as argumentation conjunctions and argumentation indicators. Argumentation conjunctions have a function of connecting two or more propositions while argumentation indicators are expressions or words like "only" and "almost", which change the argumentation potential within the boundaries of a proposition (Tseronis, 2011).

Conjunctions are words or phrases like justifications, evidences, situations, events and questions that establish a relationship between two discourses. These can be examined under three basic grammar classes (adverb, linking and coordinating conjunctions) (Özhan, 2012). The related conjunctions have been classified in various ways by the researchers according to their meanings in the sentences or according to the relationships that they establish between the units (Schiffrin, 1987; Fraser, 1999; Miltsas, Prsad, Josh and Weber, 2004; Fraser, 2005; Günay, 2007). Barton (1995) emphasizes that functions of conjunctions in the meta-discourse are important as author considers reader's expectations and shows his/her approach. 
According to Fraser (2005), discourse markers establish a correlation between the first sentence and the second sentence. Conjunctions as tools between the two units are used depending on sentence properties:

1. Syntactic (and, but, or, since, whereas, despite etc.).

2. Anaphora expressions (consequently, by contrast, therefore, in addition, however, in addition, instead etc.)

3. Connotations (according to, after all, as an alternative, as well as, above all, accordingly, likewise, again, therefore, so etc.).

Discourse markers, words or phrases-grammar units- explain how discourses, which contribute to the idea desired to be given by the author, are used before and describe their functions. Discourse markers are analysed in 15 different categories according to their functions: focus and conjunction, opposition, similarities, substitution, restructuring, attitudes, persuasion, adding, generalizations, exemplification, logical conclusion, verification and disclosure, saving time, referencing and summarizing (Dülger, 2007). In an argumentative text, author who defends his claim while presenting justifications should take into account the target audience. Discourse markers are bold written statements contained in the following consecutive sentences (Fraser, 1999).

A: I like him. So, I think he would ask to you later.

B: John did not go. And Mary did not go as well.

C: Are you going? Also, will you represent your class there?

D: Sue left too late. But he was on time.

E: I think it will fly. In the end we'll build it.

Conjunctive elements in the text are realized by markers, linking, coordination conjunctions, one under another relation conjunctions and idiomatic verbs Gunay (2007). This logical conjunction indicates arrangement between sentences and thought strings such as inter-sentences and inter thoughts cause-effect, distinctive side, and addition. These conjunctions, which enable thought to develop incrementally and to achieve the result, specify the basic regulations the among evidences. Words implies these are given in the table below (Günay, 2007).

Table 1. Logical Conjunctions

\begin{tabular}{|c|c|c|}
\hline Logical relations & The development followed by the author & Relation words \\
\hline Reason & $\begin{array}{l}\text { The author confirms previous evidence and } \\
\text { explain something }\end{array}$ & For, because, since, indeed, true, it is, in fact, though \\
\hline Result & $\begin{array}{l}\text { The author reaches a conclusion from his/her } \\
\text { previous approach }\end{array}$ & $\begin{array}{l}\text { So, then, thus, if, therefore, it follows that, when it is } \\
\text { thought in this way, and thus, ultimately, as a result, when } \\
\text { viewed from this perspective, at that point, in this case, } \\
\text { say, that is to say, now, accordingly }\end{array}$ \\
\hline Opposition & $\begin{array}{l}\text { The author refutes what he said earlier or } \\
\text { indicates the distinction between what has been } \\
\text { said before and his /her own thoughts. }\end{array}$ & $\begin{array}{l}\text { But, however, instead, though, nevertheless, despite, } \\
\text { although, nonetheless, that, whereas, being, yet, on the } \\
\text { contrary, but, also, conversely, in opposition, to the } \\
\text { contrary, to contrast, in spite of }\end{array}$ \\
\hline $\begin{array}{l}\text { Contribution } \\
\text { continuity }\end{array}$ & Author presents a group of proving list & $\begin{array}{l}\text { First, first of all, firstly, before, then, after, after that, also, } \\
\text { moreover, further, in addition, finally, as a result, as a } \\
\text { consequence, whereas, while, on the other hand, } \\
\text { erstwhile, formerly, once, tomorrow, today, yesterday, a } \\
\text { little while ago, now, just now. }\end{array}$ \\
\hline Unity" & The relationship between two things & And, as well, either, neither \\
\hline $\begin{array}{l}\text { Alternation } \\
\text { (consecutive) }\end{array}$ & Two events, conditions happen consecutively & Or $\ldots$ or, or... or vice versa, or \\
\hline Objective & & \\
\hline Comparison & & Thus, in the same way, in the same manner, according to \\
\hline
\end{tabular}

These structures which provide the link between the relations, constitute the language of justifications. In fact, understanding how they use the language that they try to prove can be very beneficial to define the units of argumentation index which is based on language observations (Tseronis, 2011). Discourse markers are used to establish meaning-based relationship between sentences while presenting justifications. Therefore, the language used in argumentative texts when the author presents justification is important. In a similar vein, Atmaca (2016) conducted a comparative discourse analysis in the summary parts of M.A thesis and Ph.D. dissertations conducted in English Language Teaching in terms of hedging and concluded that hedges used in the Ph.D. dissertations nearly double those in the M.A. theses.

In light of the literature, it can be said that there needs more research to investigate the discourse markers by student teachers in order to shed light upon an over looked area and contribute to their writing skills. The purpose of this 
research is to identify discourse markers used in justification types in Turkish language teacher candidates' argumentative texts. The sub-objectives of the research are;

1. How many categories of support and refutation justifications are found in the argumentative texts of Turkish language teacher candidates?

2. What is the usage ratio of discourse markers in justification types that are found in the argumentative texts of Turkish language teacher candidates?

\section{Method}

This part reveals information about the research model, population and sample, data collection tools and data analysis techniques.

\subsection{Research Model}

Survey model was used in this research as it was aimed to determine the categories of support and refutation justifications and to identify the discourse markers which express these categories. It is a descriptive field research in which qualitative data analysis techniques were employed (Dörnyei, 2007). Descriptive studies try to explain the interaction between situations and describe events, objects, beings, institutions, groups and various groups taking into account the relationship of actual facts with previous events and circumstances (Captain, 1995).

\subsection{Working Group}

Research includes $3^{\text {rd }}$ and $4^{\text {th }}$ year students studying in Turkish Language Teaching Department at Hatay Mustafa Kemal University, in 2014-2015 academic year. The sample of the research was obtained from 100 students who participated in the study.

\subsection{Data Collection Tool}

Argumentative writing text form was developed by researcher. The stages given below were followed during preparation of this form respectively.

a) A recent and realistic subject was chosen by the researchers and argumentative text form was created. Special attention was given to obtain recent and realistic subjects in this form.

b) The subjects were submitted to expert opinion and they were asked to give points from 1 to 5 .

c) "Argumentative Writing Text Form" was created about the subject (Argumentative text writing form was created based on the subject "Which one is more effective while applying your profession: Your ability or your training? Please write.) with the highest score (Table-2).

Table 2. Writing Subjects

\begin{tabular}{llc}
\hline Subjects & Point & $\overline{\mathrm{x}}$ \\
\hline Which one is more effective while applying your profession: Your ability or your training? Please Write. & 46 & 4.6 \\
Is intelligence innate or is it obtained later? Please Write. & 38 & 3.8 \\
Which one is more important in life to be successful? Being social or being intelligent? Please Write. & 36 & 3.6 \\
\hline
\end{tabular}

\subsection{Justification Type Identification Form}

The related literature (Schiffrin, 1987; Fraser, 1999; Weber, 2004; Coates, 2005; Fraser, 2005; Miltsaski Prsad, Joshi and; Günay, 2007; Özhan, 2012) was utilized for the preparation of this form and it was formed by the discourse markers used for justifications. At this point, a total of 118 markers in 9 categories were determined (reason and result, opposition, comparisons, exemplification, contribution-continuity, addition, distinction, mutual assumption). After reading texts when a new expression was observed, a new category and statements were added to the form. Thus, the latest version of the form was formed by adding 2 categories (asking questions, condition) and 3 discourse markers. The final version of the table includes 121 discourse markers in 11 justification types (Table 3). 
Table 3. Justification Type Identification Form

\begin{tabular}{|c|c|c|}
\hline Justification types & Meaning relationship & Discourse markers \\
\hline Reason & $\begin{array}{l}\text { Justifications are verified or explained by a } \\
\text { situation or an event. }\end{array}$ & $\begin{array}{l}\text { Because, for this, for, as, since, indeed, true, such, } \\
\text { indeed, though }\end{array}$ \\
\hline Result & Justifications are finalized. & $\begin{array}{l}\text { Because of, hence, as a matter of fact, because of this, } \\
\text { so, then, thus, if, therefore, it follows that, when it is } \\
\text { thought in this way, and thus, ultimately, as a result, } \\
\text { when viewed from this perspective, at that point, in } \\
\text { this case, say, that is to say, now, accordingly }\end{array}$ \\
\hline Opposition & Differences between justifications are noted. & $\begin{array}{l}\text { yet, but, though, otherwise, however, if it were, or else, } \\
\text { nevertheless, although, on the other side, whereas, in } \\
\text { contrast, still, whereas, only, on the contrary, contrary } \\
\text { to, conversely, in contradiction to, rather, in contrast to }\end{array}$ \\
\hline Contribution-continuity & Multiple justifications are presented. & $\begin{array}{l}\text { Exactly, besides, on the other hand, here, also, as seen, } \\
\text { again, no doubt, first, first of all, firstly, before, then, } \\
\text { after, after that, also, moreover, further, in addition, } \\
\text { finally, as a result, as a consequence, whereas, while, } \\
\text { on the other hand, erstwhile, formerly, once, tomorrow, } \\
\text { today, yesterday, a little while ago, now, just now. }\end{array}$ \\
\hline Addition & Justifications come consecutively. & With, and, as well, both, as well as, either \\
\hline Distinction & Justification are distinguished. & Or, or... or vice versa, else \\
\hline Comparison & $\begin{array}{l}\text { Justifications are compared according to their } \\
\text { specifications. }\end{array}$ & $\begin{array}{l}\text { More importantly, however, the best, the best way, } \\
\text { according to, the most important of them, first of them, } \\
\text { first of all, so in the same way, the same way, }\end{array}$ \\
\hline Mutual assumption & $\begin{array}{l}\text { Justifications are considered as a situation or } \\
\text { an event temporarily. }\end{array}$ & $\begin{array}{l}\text { Imagine a ..., let's think a....., Let, let's think that, let it } \\
\text { be a ... }\end{array}$ \\
\hline Exemplification & Justifications are exemplified. & $\begin{array}{l}\text { For example, if I were to give an example, if we give } \\
\text { an example, there are many examples that, if one need } \\
\text { to describe it with another example, for instance, } \\
\text { another example is }\end{array}$ \\
\hline Asking question & $\begin{array}{l}\text { Questions are asked while presenting } \\
\text { justifications. }\end{array}$ & How \\
\hline Condition & $\begin{array}{l}\text { Conditions are presented for the realization of } \\
\text { justifications. }\end{array}$ & if \\
\hline
\end{tabular}

\subsection{Data Analysis}

Since data were collected from non-numerical data, qualitative data analysis procedures were employed in the study. The texts were analysed by using content analysis method. Descriptive statistics (frequency (f), percentage (\%) analysis were also used in the analysis of the data collected in this study to benefit from the complementary purposes of numbers and words. The discourse markers used in justification types were shown with sample sentences. A second coder aprt from the researcher was also involved in data analysis procedures to ensure inter-rater reliability (Miles \& Huberman, 1994). They compared their coding after the finalization of $25 \%$ of data collection and the agreement level was gound to be $80 \%$. In the second meeting held after the finalization of $100 \%$ of data analysis, the agreement level was found to be $90 \%$. The coders continued to discuss on the disagreed categories until there was complete agreement between them.

\section{Results}

In this section, the data obtained from the study were presented in tables.

Table 4. Distribution of justification types according to justifications

\begin{tabular}{|c|c|c|c|c|}
\hline \multirow{2}{*}{ Justification Type } & \multicolumn{2}{|c|}{ Support justification } & \multicolumn{2}{|c|}{ Refutation justification } \\
\hline & $f$ & $\%$ & $\mathrm{f}$ & $\%$ \\
\hline Reason & 43 & 19.11 & 8 & 16 \\
\hline Result & 12 & 5.33 & 1 & 2 \\
\hline Opposition & 26 & 11.55 & 17 & 34 \\
\hline Contribution-continuity & 18 & 8 & 3 & 6 \\
\hline Addition & 32 & 14.22 & 4 & 8 \\
\hline Distinction & 6 & 2.66 & 1 & 2 \\
\hline Comparison & 9 & 4 & 2 & 4 \\
\hline Mutual assumption & 10 & 4.44 & - & 0 \\
\hline Exemplification & 31 & 13.77 & 7 & 14 \\
\hline Asking question & 19 & 8.44 & 4 & 8 \\
\hline Sequencing & 4 & 1.77 & 1 & 2 \\
\hline Condition & 5 & 2.22 & 2 & 4 \\
\hline Total & 225 & 100 & 50 & 100 \\
\hline
\end{tabular}

According to Table 4, a total of 275 justifications including support justifications ( $\mathrm{f}=225)$ and refutation justifications ( $\mathrm{f}$ 
$=50$ ) were presented in the texts produced by the students. Justification types, which are most widely used for support justifications, are reasoning (\% 19.11), addition (\%14.22), exemplification (\%13.77) and opposition (\%11.55). The least used justification types are distinction (\%2.66), condition (\%2.22) and sequencing (\%1.77). Opposition (\%34) is the most widely used justification type for refutation justifications whereas conclusion, distinction and sequencing (\%2) are the least used ones.

Table 5. Use of Justification Types with Discourse Markers

\begin{tabular}{|c|c|c|}
\hline Justification Type & $\mathrm{n}$ & Discourse markers \\
\hline Reason & 4 & Because, for this, for \\
\hline Result & 5 & So, thus, in fact, that's why... \\
\hline Opposition & 13 & $\begin{array}{l}\text { But, nevertheless, though, otherwise, however, if it were, despite, although, on the other } \\
\text { hand, yet, whereas }\end{array}$ \\
\hline Contribution-continuity & 10 & Certainly, besides, on the other hand, here, also, again, no doubt, it is said that... then \\
\hline Addition & 8 & With, and, as well, both, as well as, either \\
\hline Distinction & 2 & or, else \\
\hline Comparison & 5 & $\begin{array}{l}\text { More importantly, however, the best, the best way, according to, the most important of } \\
\text { them, first of them, first of all }\end{array}$ \\
\hline Mutual assumption & 5 & Imagine a ..., let's think a......, Let, let's think that, let it be a ... \\
\hline Exemplification & 7 & $\begin{array}{l}\text { For example, if I were to give an example, if we give an example, there are many } \\
\text { examples that, if one need to describe it with another example, for instance, another } \\
\text { example is }\end{array}$ \\
\hline Asking question & 1 & How \\
\hline Condition & 2 & if \\
\hline Total & 62 & \\
\hline
\end{tabular}

Discourse markers $(n=62)$ were identified in 11 justification types according to Table 5. Examples, where these discourse markers were employed, are presented in Table 5 through sample sentences.

Table 6. Examples Regarding the Use of Justification Types with Discourse Markers

\begin{tabular}{|c|c|}
\hline Justification Type & Sentences \\
\hline Reason & $\begin{array}{l}\text { When the students in schools are asked about their favourite teacher type, I } \\
\text { think that answer given is talented teacher indeed. Because, students use this } \\
\text { caption for teachers who love his / her job, immanence this job, try to do } \\
\text { everything and meet moral and material interest and learning needs. }\end{array}$ \\
\hline Result & $\begin{array}{l}\text { Implementation stage is the stage where received education is presented. } \\
\text { Indeed, importance of education you receive fully reveals at this point. }\end{array}$ \\
\hline Opposition & $\begin{array}{l}\text { While applying your profession talent carries importance as well as education. } \\
\text { But talent alone is not effective. }\end{array}$ \\
\hline Contribution-continuity & $\begin{array}{l}\text { If we consider Turkish language teaching, a Turkish language teacher should be } \\
\text { social first and possess god communication skills. Besides this, He / she should } \\
\text { possess a talent in terms of listening, reading, writing and speaking. }\end{array}$ \\
\hline Addition & These capabilities pale without education and they become useless. \\
\hline Distinction & $\begin{array}{l}\text { People have to continue a profession, which they do not want, for } 30-40 \text { years } \\
\text { because of being misled although not possessing a talent } \text { or lack of information. }\end{array}$ \\
\hline Comparison & $\begin{array}{l}\text { The lack of information disappears by time or eliminated by experience. As for } \\
\text { ability, it is a feature that should be possessed by a teacher from the beginning } \\
\text { till the end. }\end{array}$ \\
\hline Mutual assumption & $\begin{array}{l}\text { Suppose there is a student who has the ability of teaching. } \\
\text { If we were to tell it with another example let's imagine a merchant who will }\end{array}$ \\
\hline Exemplification & $\begin{array}{l}\text { depart for a long journey. This man takes food, drink and his clothes which are } \\
\text { called "feeder" colloquially. }\end{array}$ \\
\hline Asking question & $\begin{array}{l}\text { How can he / she transfer the education he / she received to the students } \\
\text { effectively? }\end{array}$ \\
\hline Condition & $\begin{array}{l}\text { If you educate students and put them into a certain mould, and if you read about } \\
\text { necessary information about this subject then you apply your profession } \\
\text { perfectly and you're qualified. }\end{array}$ \\
\hline
\end{tabular}

\section{Conclusion, Discussion and Implications}

Argumentative text is the text structure which is formed by refuting the opposed idea while defending his / her own ideas about a subject. Justification, which is taken as a secondary element in this text structure, is studied under two different categories as support justification and refutation justification. 11 justification types were defined as a result of this study: reason and result, opposition, contribution-continuity, addition, distinction, comparison, mutual assumption, exemplification, asking questions, sequencing and condition. 62 discourse markers were used to express these justification types. 62 discourse markers from 100 texts were detected for justification types: Reason "because, to do so, meanly, for" ( $(n=4)$; result so, in fact, that's why, so that" $(n=5)$; opposition "But, otherwise, however, if it were, despite, on other side, whereas" ( $\mathrm{n}=11)$; contribution and continuity "definitely, with that, on the other hand, here, also, 
that, again, no doubt, it is said that, then" ( $\mathrm{n}=10)$; addition "and, with, as well, as well as, either, neither " $(\mathrm{n}=8)$; distinction " else, or " $(\mathrm{n}=2)$; comparison $(\mathrm{n}=8)$; mutual assumption $(\mathrm{n}=5)$; exemplification $(\mathrm{n}=7)$; asking questions $(\mathrm{n}=1)$; and condition $(\mathrm{n}=2)$. Dülger (2007) identified 803 discourse markers in 76 texts in his study carried out to assess discourse marker use of English language teaching students. After writing training given to the students, this figure reached to 1054. According to the results of our survey, it is thought that training given to teachers regarding argumentative text justifications has a positive effect on the raise of discourse markers use ratio.

A total of 275 justifications including support justifications $(f=225)$ and refutation justifications $(f=50)$ were presented in student texts. According to the study carried out by Tiryaki (2011) on university students, the average use of support justification is 1.31 while refutation justification is 0.32 . This result is in line with the results of our study. Support justification ratio used by students during proving their ideas is higher than the use of refutation justification ratio. It is identified through different research studies that the most difficult element faced by the teacher candidates during writing argumentative text is the opposing idea (Nussbaum and Schraw, 2007; Tiryaki, 2011). It can be said that expressing one's own opinion regarding a topic is easier than developing an idea against the opposing thought. Although they can generate ideas about opposing thought; in general, they have difficulties in putting down it on paper (Knudson, 1992; Stapleton, 2001). However, defining and refuting opposing idea in a clear and strong way is a factor which raises credibility of the author (Nussbaum \& Schraw, 2007).

Justification types, which are most widely used for support justifications, are reasoning (\% 19.11), addition (\%14.22), exemplification (\%13.77) and opposition (\%11.55). The least used justification types are distinction (\%2.66), condition (\%2.22) and sequencing (\%1.77). Opposition (\%34) is the most widely used justification type for refutation justifications whereas conclusion, distinction and sequencing (\%2) are the least used ones. Ozhan (2012) analysed 3 conjunctions "but, though and although" according to Turkish (TICLE) and the American sub-collection (ALOCNESS). As a result of this analysis, expressions showing argumentative structure such as claim, opposition, refutation are used more frequently in ALOCNESS tasks for the purposes of both argumentation development and opposition statement. These markers exist in our study in opposition and contribution-continuity categories. Cetinkaya, Ülper and Hamzaday1 (2014) studied conjunction use of Grade 4, 8 and 12 students in their written expressions. It is observed that sequencing conjunctions are the most widely used ones in all classes. Sequencing conjunctions are classified into 4 groups: temporal (before, after, later), causal (because, and as), opposition (but, for example, though) and expansion (or, both). According to the results of our survey, the most-commonly-used discourse markers contained in justification types are consistent with the results of this research. According to Coates (2005), the most-widely-used conjunction elements in narrative expressions of elementary school students are "additive conjunction elements" (\%41.7) whereas the least-used ones are "example conjunction elements" (\%0.3). These results suggest that differences arising from the text structure lead to a difference in discourse markers use ratio. While exemplification is applied more in argumentative text structure, in narrative text, the authors use addition conjunction elements more frequently to sequence the event flow and to show the relations between events.

Examining the justification in the argumentative texts, this study is considered to have importance for being the first in the field. Justification constitutes a string that allows people to present their opinions in a powerful way. This string, through which people can put forward their identities, can be experimentally studied in different samples in a phased manner. The argumentative text structure, where the element "justification" is the most prominent, can be taught in a phased manner with reference to the curriculum of the MEB's (Ministry of National Education) (2012) Writing and Writing Skills Course. In those phases, the process should be planned by the instructor taking into account the use of discourse markers in these justification types while creating supporting and refuting justifications in justification types. They can be taught in the light of this study and taking into consideration the categorization of discourse markers.

\section{References}

Akıguet, S., \& Piolat, A. (1996). Insertion of connectivesby 9 to 11-year-old children in an argumentative text. Argumentation, 10, 253-270. http://dx.doi.org/10.1007/BF00180728

Atmaca, Ç. (2016). Comparison of hedges in M.A. Theses and Ph.D. dissertations in ELT. Journal of World of Turks, $8(2), 309-325$.

Barton, E. L. (1995). Contrastive and noncontrastive connectives. Metadiscourse functions in argumentation. Written Communication, 12(2), 219- 240. http://dx.doi.org/10.1177/0741088395012002003

Captain, S. (1995). Scientific research and statistical techniques. Ankara: Rehber Publishing House.

Çetinkaya, G., Ülper, H., \&Hamzadayı, E. (2014). Views on theuse of connectives in students' writtendiscourse. In H. Arslan, G. Rata, E. Kocatörük\& M. A. İçbay (Eds.). Multi-disciplinary perspectives on education (pp. 471-476). Newcastle: Cambridge Scholars Publishing 
Dörnyei, Z. (2007). Research methods in applied linguistics. Quantitative, qualitative and mixed methodologies. New York: Oxford University Press.

Dülger, O. (2007). Discourse markers in writing. Selçuk University, Journal of the Institute of Social Sciences, 18, 257-270.

Fraser, B. (1999). What are discourse markers? Journal of Pragmatics, 31(7), 931-952. https://doi.org/10.1016/S0378-2166(98)00101-5

Fraser, B. (2005). Towards a theory of discourse markers. In K. Fischer (Ed.). Approaches to Discourse Particles (pp. 189-205). Oxford: Elsevier Press.

Günay, D. V. (2007). Text information. Istanbul: Multilingual Publications.

Günay, D. V. (2013). Discourse analysis. Istanbul: Papatya Publishing.

Kıran, Z., \& Eziler, K. A. (2006). Introduction to linguistics. Ankara: Seçkin Publishing.

Knudson, R. E. (1992). The development of writing argumentation: an analysis and comparison of argumentative writing for grade levels. Child Study Journal, 22(3), 167-184.

Miles, M. B., \& Huberman, A. M. (1994). Qualitative data analysis. London: Sage Publication.

Miltsakaki, E., Prasad, R., Joshi, A., \& Webber, B. (2004). Annotating discourse connectives and their arguments. In Proceedings of the HLT/NAACL Workshop on Frontiers in Corpus Annotation. Boston, MA.

Nussbaum, M. E., \& Schraw G. (2007). Promoting argument- counter argument integration in students' writing. The Journal of Experimental Education, 76(61), 59-92. https://doi.org/10.3200/JEXE.76.1.59-92

Özhan, D. (2012). A comparatıve analysis on the use of but, however and although in the university students' argumentative essays: A Corpus-Based Study On Turkısh Learners of English and American Native Speakers. (PhD Thesis, Middle East Technical University). Retrieved from https://tez.yok.gov.tr/Ulusal Tez Merkezi

Passerat, D. Ö. (2013). Justification in newspaper discourse.. International Journal of Social Sciences Humanities, 1(2), 169-184.

Schiffrin, D. (1987). Discourse markers. Cambridge: Cambridge University Press. https://doi.org/10.1017/CBO9780511611841

Stapleton, P. (2001). Assessing critical thinking in writing of Japanese university students. Written Communication, 18, 506-548. https://doi.org/10.1177/0741088301018004004

Tiryaki, E. N., \& Y1lmaz, Z. (2016). Studies-International Periodical for the Languages, Literature and History of Turkish or Turkic, 11(3), 2193-2208.

Toulmin, S. E. (1958). The uses of argument. Cambridge: Cambridge University Press.

Tseronis, A. (2011). From connectives to argumentative markers: A quest for markers of argumentative moves and of related aspects of argumentative discourse. Argumentation, 25(4), 427-447.

https://doi.org/10.1007/s10503-011-9215-x

Vardar, B. (2002). A glossary of explanatory linguistics terms. Istanbul: Multilingual Publications.

\section{Copyrights}

Copyright for this article is retained by the author(s), with first publication rights granted to the journal.

This is an open-access article distributed under the terms and conditions of the Creative Commons Attribution license which permits unrestricted use, distribution, and reproduction in any medium, provided the original work is properly cited. 